\title{
Economic Analysis of Used Cooking Oil Supply Chain for Biofuel in Special Region of Yogyakarta
}

\author{
Rianti Indah Lestari ${ }^{1}$ \\ $\left\{\right.$ riantyindah29@gmail.com ${ }^{1}$ \} \\ Sari Mulia University, Banjarmasin, South Kalimantan ${ }^{1}$ \\ *riantyindah29@gmail.com
}

\begin{abstract}
Biofuel as suitable substitute for fossil fuel can be produced from industrial and municipal waste, used cooking oil. High consumption of cooking oil in Indonesia gives a nice opportunity for cooking oil as material for producing biofuel. According high potentiality and high availability of used-cooking oil in culinary industries, Yogyakarta would be a city of biofuel production from the oil. The aim of this research is to analyze an economic factor towards the supply chain design of biofuel in D.I.Y at strategic level supply chain. Method of thesis is to build mathematical model which defined by Excel spreadsheet and solved by CPLEX optimizer. Otherwise, for calculate an economic analysis using revenue cost ratio ( $\mathrm{R} / \mathrm{C}$ ratio). Based on $\mathrm{R} / \mathrm{C}$ ratio method then it obtanained rasio value $\mathrm{R} / \mathrm{C}>1$. Therefore can be summarized that proper investment because of given production profit for each day.
\end{abstract}

Keywords: Biofuel, Economic Analysis, Used Cooking Oil, CPLEX optimizer, Gravity Location Model

\section{Introduction}

Energy is an important natural source for life. One of energy which related to life activities is fossil fuel substances. According to economical sector, Indonesia energy growth during 2011-2012 increased about 4,04\% and the biggest user comes from transportation sector about $65 \%$. Increasing of using energy without balance of supply ability would be impacted in limitation of oil reserves. Therefore, we need renewable energy source for using, which is biofuel.

Basically, biofuel is made from virgin wood, food plant, agriculture crop, food waste and waste of production process with bioethanol and biodiesel potential. Consider to high consuming of frying oil in Indonesia, so that used cooking oil has large oppoortunityas feedstock of biofuel. For encourage building up of industrial scale of biofuel plant quickly, creating for supply chain of used cooking oilis needed. Due to the fact that high culinary industry trading and supported by eco mini plant biofuel project of Chemical Engineering Department Gadjah Mada University, Special Region of Yogyakarta (Daerah Istimewa Yogyakarta/ D.I. Yogyakarta) can be chosen as a country for developing biofuel industry from used cooking oil.

For fulfilling biofuel stock as fossil fuel mixing, especially for diesel fuel, then at least needed 5\% biofuel over total of diesel fuel necessary in D.I.Y. As a first step to analyze potential and feedstock quantity, mapping of used cooking oil supplier is needed. Proposed design for supply chain cover mapping of feedstock supplier and strategic design of feedstock supply, facility location, capacity of facility and distribution flow from product to facility. 
Moreover, economic analysis is regarded as one of the important thing for sustainable future for biofuel supply chain design from used cooking oil. This research aims to analyze an economic factor towards the supply chain design of biofuel in D.I.Y.

\section{Collecting Data}

\subsection{Data of Feedstock Source}

Data of feedstock is collected from 303 used cooking oil suppliers whom come from 20 fast food restaurants, 153 food industries and 129 caterings. The supplier distributed from 4 regencies and a city i.e. Sleman regency, Bantul regency, Kulon Progo regency, Gunung Kidul regency, and Yogyakarta city. Estimated feedstock data from daily consumption of used cooking oil will be scaled up base on supplier quantities. Average of daily consumption of used cooking oil from fast food restaurant, food industries and caterings are 35 litre/ day, 3 litre/day, and 5 litre/day, respectively. Supplier mapping result showed 2.561 litre/day of feedstock quantities.

\subsection{Data of Collection Bin}

Determining of collection bin location uses gravity location model base on supplier source coordinate. First, determining new facility of location, the assumed base on the biggest feedstock location, i.e. Danurejan and Depok. Determining of collection bin capacity was informed by Commercial and Waste and Recycling Services [1]. This research assumed that there are two stores for each, operated in 660 litre/day and 940 litre/day.

\subsection{Data of Biofuel Plant}

Determining of plant was informed from investment potential and DIY regions characteristic. Plant capacity was estimated from relevant research by [7] about 3000 litre/day. The estimation for plant establisment cost will be determined from parametric method [8]

\subsection{Data of Transportation Mode}

Transportation mode uses three wheels motor. Motor will be used for carrying used cooking oil to collection bin and or to biofuel plant. Motor price refers to motor price in 2015.

\subsection{Transportation Cost Matrix}

Transportation line is started from supplier to store and or directly to biofuel plant. Transportation cost estimation refers to fuel efficiency over vehicles capacity [2].

$$
\begin{aligned}
& \text { constant of fuel efficiency with load }=(1- \\
& \left.\frac{\left(\begin{array}{c}
\text { Fuel efficiency per } 0.45 \mathrm{~kg} \times \text { conversion litre to } \mathrm{kg} \times \\
\text { the number of feedstock delivered) }
\end{array}\right.}{\text { conversion } 100 \mathrm{lb} \text { to } \mathrm{kg}}\right)
\end{aligned}
$$

transportation cost $=\frac{\text { The diesel fuel cost per litre } \times \text { distance matrix between facilities }}{\text { The distance traveled of diesel fuel per litre for } \text { fuel ef ficiency unload } \times}$ 


\section{Mathematical Model Formulation}

Component of mathematical model are the distance of feedstock supplier to collection bin and feedstock supplier to plant, cost of biofuel plant investment, collection bin cost, cost of vehicle and transportation cost. Constraints of mathematical model includes used-cooking oil supply, capacity of collection bin and plant. Objective function is optimization of usedcooking oil supply chain by minimizing transportation cost and cost of investment plant.

\section{Mathematical Model Development and Software Implementation}

Mathematical model is developed by using Microsoft Excel 2010 to identify optimization case in spreadsheet. The component which has been defined is parameter data, decision variable, objective function and constraints. After developing model, then it will be solved by CPLEX V12.1 optimizer in Microsoft Excel Add-in [4].

\section{Result and Discussion}

\subsection{System Description}

Basic model of used-cooking oil supply chain for biofuel plant in D.I.Y can be showed in

Figure 1.

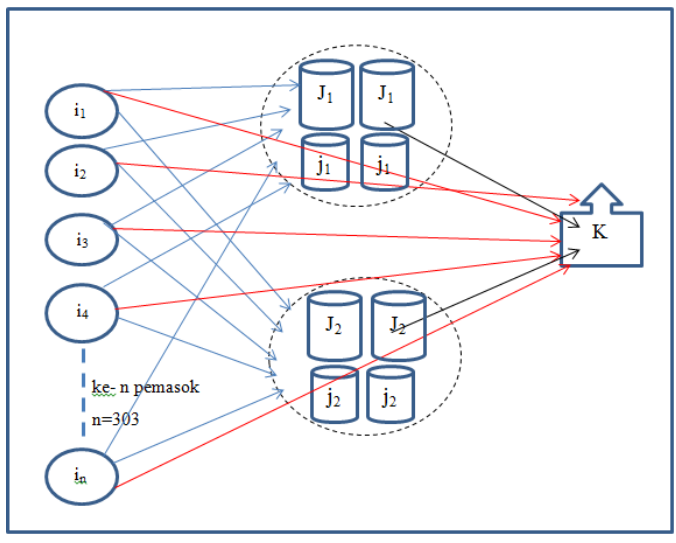

Fig. 1. Illustration of Used Cooking Oil Supply Chain

\subsection{Mathematical Model Development}

a. Variable

$S_{i} \quad$ The used cooking oil volume produced per day (litre)

$G_{j} \quad$ Daily capacity of medium collection bin at J point (litre)

$g_{j} \quad$ Daily capacity of small collection bin at j point (litre)

$K_{k} \quad$ Daily capacity of biofuel plant at K point

$P_{j} \quad$ Cost of medium collection bin at J point

$p_{j} \quad$ Cost of small collection bin at $\mathrm{j}$ point

$F_{k} \quad$ Cost of biofuel plant investment $\mathrm{K}$

$T$ Cost of vehicle 
$T_{c} \quad$ Transportation cost

$d_{i j} \quad$ Distance between feedstock source i to collection bin $\mathrm{j}(\mathrm{km})$

$d_{j k} \quad$ Distance between collection bin $\mathrm{j}$ to biofuel plant $\mathrm{k}(\mathrm{km})$

$d_{i k} \quad$ Distance between feedstock source i to biofuel plant $\mathrm{j}(\mathrm{km})$

C The diesel fuel cost per litre $=$ Rp6900,00

$D_{m t}$ The distance traveled of diesel fuel per litre for three wheels motor $(\mathrm{km} / \mathrm{ltr})$

$E_{m t} \quad$ Fuel efficiency per $0.45 \mathrm{~kg}$ for three wheels motor

1 litre of fuel $=0.9 \mathrm{~kg}$

$100 \mathrm{lb}=0.45 \mathrm{~kg}$

\section{b. Decision Variable}

$X_{i j} \quad$ The number of feedstock delivered from supplier at $\mathrm{i}$ point to $\mathrm{j}$ point

$X j_{k} \quad$ The number of feedstock delivered from collection bin at $\mathrm{j}$ point to biofuel plant at $\mathrm{k}$ point

$X_{i k} \quad$ The number of feedstock delivered from supplier at i point to biofuel plant at k point

$Y_{j} \quad$ A binary variable 0 and 1,1 if medium collection bin is visited, 0 otherwise

$y_{j} \quad$ A binary variable 0 and 1,1 if small collection bin is visited, 0 otherwise

$Y_{k} \quad$ A binary variable 0 and 1,1 if biofuel plant is visited, 0 otherwise

\section{c. Objective Function}

$$
\begin{aligned}
& F C D L=\sum_{j=1}^{J}\left(P_{j} Y_{j}\right) \\
& F C D S=\sum_{j=1}^{J}\left(p_{j} y_{j}\right) \\
& F C P L=\sum_{k=1}^{K}\left(F_{k} Y_{k}\right) \\
& T C_{1}=\frac{C \times \sum_{i=1}^{I} \sum_{j=1}^{J} d_{i j}}{D m t \times E_{m t}} \\
& T C_{2}=\frac{C \times \sum_{j=1}^{J} \sum_{k=1}^{K} d_{j k}}{D m t \times E_{m t}} \\
& T C_{3}=\frac{C \times \sum_{i=1}^{I} \sum_{k=1}^{K} d_{i k}}{D m t \times E_{m} t}
\end{aligned}
$$

For variable $E_{m t}$ is refers to equation (1) and (2)

$$
T C_{1}=\frac{c \times \sum_{i=1}^{I} \sum_{j=1}^{J} d_{i j}}{D m t \times\left(1-\frac{\left(0.007 \times 0.9 \times X_{i j}\right)}{0.45}\right)}
$$




$$
\begin{aligned}
& T C_{2}=\frac{C \times \sum_{i=1}^{I} \Sigma_{j=1}^{J} d_{j k}}{D m t \times\left(1-\frac{\left(0.007 \times 0.9 \times X_{j k}\right)}{0.45}\right)} \\
& T C_{3}=\frac{C \times \sum_{i=1}^{I} \Sigma_{j=1}^{J} d_{i k}}{D m t \times\left(1-\frac{\left(0.007 \times 0.9 \times X_{i k}\right)}{0.45}\right)}( \\
& \text { Minimasi } Z=\left\{F C P L+F C D S+F C P L+T C_{1}+T C_{2}+T C_{3}\right\}
\end{aligned}
$$

\section{d. Constraint}

$$
\begin{aligned}
& \sum_{i=1}^{I} S_{i} \geq \sum_{i=1}^{I} \sum_{j=1}^{J} X_{i j}+\sum_{i=1}^{I} \sum_{k=1}^{K} X_{i k} \\
& \sum_{i=1}^{I} \sum_{j=1}^{J} X_{i j} \leq \sum_{j=1}^{J} \sum_{k=1}^{K} X_{j k} \\
& \sum_{j=1}^{J} Y_{j}+\sum_{j=1}^{J} y_{j} \leq 1 \\
& \sum_{i=1}^{I} \sum_{j=1}^{J} X_{i j} \leq \sum_{j=1}^{J} G_{j} Y_{j} \\
& \sum_{i=1}^{I} \sum_{j=1}^{J} X_{i j} \leq \sum_{j=1}^{J} g_{j} y_{j} \\
& \sum_{i=1}^{I} \sum_{k=1}^{K} X_{i k} \leq \sum_{k=1}^{K} K_{k} Y_{k} \\
& \sum_{j=1}^{J} \sum_{k=1}^{K} X_{j k} \leq \sum_{k=1}^{K} K_{k} Y_{k} \\
& \sum_{i=1}^{I} S_{i}=\sum_{i=1}^{I} \sum_{j=1}^{J} X_{i j}+\sum_{i=1}^{I} \sum_{k=1}^{K} X_{i k} \\
& \sum_{i=1}^{I} \sum_{j=1}^{J} X_{i j}=\sum_{j=1}^{J} \sum_{k=1}^{K} X_{j k} \\
& X_{i j} \geq 0, X_{j k} \geq 0, X_{i k} \geq 0, Y_{j} \geq 0, y_{j} \geq 0, Y_{k} \geq 0, y_{k} \geq 0
\end{aligned}
$$

\subsection{Analysis of Cost Component}

Many assumptions are used for calculating cost of collection bin, cost of biofuel plant investment and cost of vehicle. Calculating is based on equation of Equal Payment Series Capital Recovery Amount for daily basis and 300 day/year capacities.

\subsection{Analysis of Optimization Result}

Result of basic model optimization can be showed at Figure 2. Table 1 showed that no used-cooking oil (i) directly carried to biofuel plant $(\mathrm{K})$ but rather carried to collecting bin by selecting two small capacities at Danurejan $\left(\mathrm{J}_{1}\right)$ and two medium capacities at Depok $\left(\mathrm{J}_{2}\right)$. Allocation of used-cooking oil quantities for each bin is 681 liter in danurejan and 1880 liter in Depok-Sleman are given in Table 2. According to data process calculated cost of transportation about Rp. 750. 615, 40, cost of collection bin about Rp. 2.026, 00, cost of vehicle about Rp. 7.836, 80 and cost of biofuel plant investment about Rp. 1.308.441,00. Thus, total cost for each day is about Rp. 3.047.279, 26 .

Figure 3. showed that there are no used-cooking oil directly carried out to biofuel plant (K) but rather will be accumulated provisionally into two small bin at Danurejan $\left(\mathrm{j}_{1}\right)$ for 900 liter and into two medium bin for 1880 liter (Table 3 and Table 4). Based on data processing calculated cost of transportation about Rp. 760.895, 50, cost of collection bin about Rp 
2.026.00, 00, cost of vehicle about Rp. 7.836, 80 and cost of biofuel plant investment about Rp. 852.220,80, so that total cost for each day is about Rp. 3.033.330, 55.

Table 1.

\begin{tabular}{|c|c|c|c|}
\hline \multirow{2}{*}{ Description } & \multicolumn{3}{|c|}{ Facility options } \\
\cline { 2 - 3 } & \multicolumn{2}{|c|}{ Collection bin } & \multirow{2}{*}{ Plant } \\
\cline { 2 - 3 } & Danurejan & Depok & \\
\hline Fixed cost & 1099.8 & 1099.8 & 1308441 \\
\hline Facility capacity & 1880 & 1880 & 3000 \\
\hline \multirow{2}{*}{ Description } & \multicolumn{2}{|c|}{ Facility options } \\
\cline { 2 - 3 } & \multicolumn{2}{|c|}{ Collection bin } & \multirow{2}{*}{ Plant } \\
\cline { 2 - 3 } & Danurejan & Depok & \\
\hline Fixed cost & 1099.8 & 1099.8 & 1308441 \\
\hline Facility capacity & 1880 & 1880 & 3000 \\
\hline Select facility & 0 & 1 & 0 \\
\hline Fixed cost & 926.4 & 926.4 & \\
\hline Facility capacity & 1320 & 1320 & \\
\hline Select facility & 1 & 0 & \\
\hline
\end{tabular}

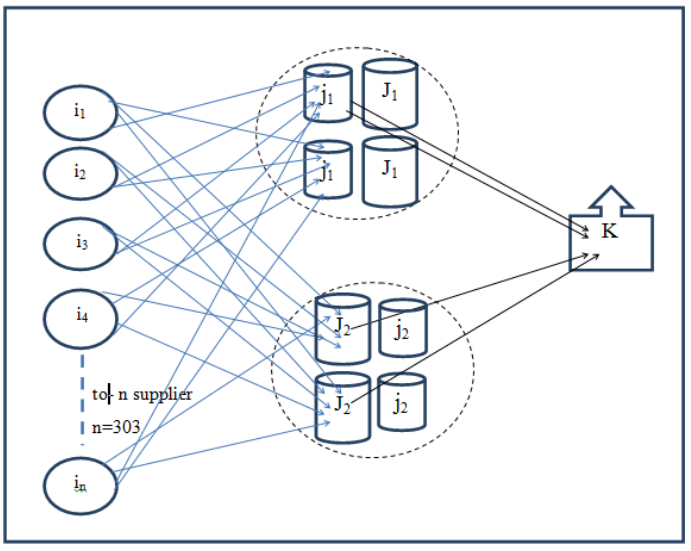

Fig. 2.
Table 2.

\begin{tabular}{|c|c|c|c|}
\hline \multirow{2}{*}{ Description } & \multicolumn{3}{|c|}{ Pemilihan fasilitas } \\
\cline { 2 - 3 } & \multicolumn{2}{|c|}{ Collection bin } & \multirow{2}{*}{ Plant } \\
\cline { 2 - 3 } & Danurejan & Depok & \\
\hline Cost facility & 0 & 1099.8 & 0 \\
\hline Flow-facility & 0 & 1880 & 0 \\
\hline \multirow{3}{*}{ Description } & \multicolumn{3}{|c|}{ Pemilihan fasilitas } \\
\cline { 2 - 3 } & \multicolumn{2}{|c|}{ Collection bin } & \multirow{2}{*}{ Plant } \\
\cline { 2 - 3 } & Danurejan & Depok & 0 \\
\hline Cost facility & 0 & 1099.8 & 0 \\
\hline Flow-facility & 0 & 1880 & 0 \\
\hline Cost facility & 926.4 & 0 & 0 \\
\hline Flow-facility & 900 & 0 & \\
\hline
\end{tabular}

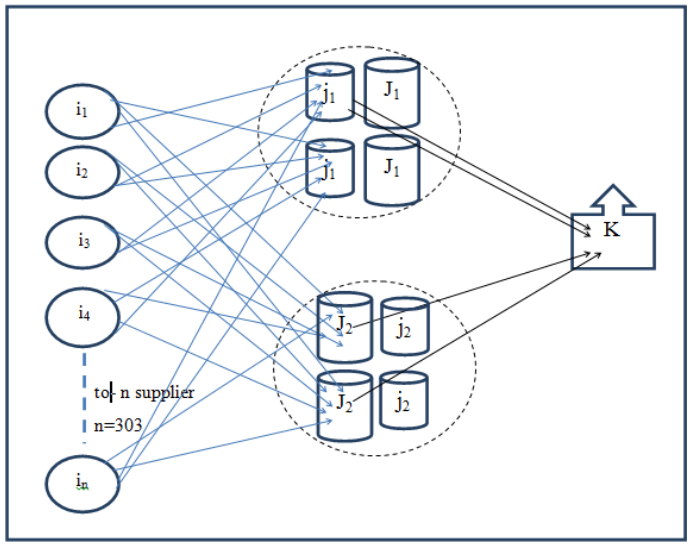

Fig. 3.

\section{Economic Analysis}

Proper analysis that used in this research is analysis of revenue cost ratio ( $\mathrm{R} / \mathrm{C}$ ratio). The analysis is aimed to analyze economical profit level by calculating comparison between revenue and expenditure [5]. The parameter ratio are described below:

$\mathrm{R} / \mathrm{C}$ Ratio $=1$ means business not profit and not loss

$\mathrm{R} / \mathrm{C}$ Ratio $<1$ means business loss

$\mathrm{R} / \mathrm{C}$ Ratio $>1$ means business profit

In this research the costs used to calculate are investment costs and operational costs. Those costs are refers to the previous reserach by [6]. Using investment cost and operational cost that needed to this research, so that calculated rasio value $\mathrm{R} / \mathrm{C}>1$. Therefore can be summarized that proper investment because of given production profit for each day.

\section{Conclusion and Suggestion \\ 7.1 Conclusion}


The research created the model of used-cooking oil supply chain for 303 supplier spread in regencies of DIY. Data from food industry, catering and fast food restaurant will result map of network between basic model and sensitivity model. For basic model and sensitivity model optimization assumed that there is no feedstock delivered from supplier to plant but rather feedstock will be collected in collection bin at Danurejan and Depok. After that, feedstock will be carried to the plant.

Mathematical model showed that two collection sites will be created i.e. small collection bin in Danurejan and medium collection bin in Depok. The number of feedstock distributed to Danurejan for 681 liter and 1880 liter for Depok. Sensitivity analysis over increasing of usedcooking oil quantities doesn't affect the decision of opening collection sites. It is impact for distribution to each facility and cost of transportation, cost of collection bin, cost of vehicle, and cost of biofuel plant investment. Therefore, design of used cooking oil supply chain for biofuel in DIY will minimize the total cost about Rp3.047.279,26/day.

\subsection{Suggestion}

a. Model design not only concerned to minimizing cost but environment effect is needed especially for emission levels.

b. Supplier source is added so that biofuel requirement in DIY can be fulfilled.

\section{References}

[1] Bournemouth Borough Council: Commercial waste dan recycling services. (2011). http://www.bournemouth.gov.uk/, (online accessed 9 Desember 2014).

[2] Broda, R., dan Casadei, A.: Impact of Vehicle Weight Reduction on Fuel Economy for Various Vehicle Architectures, Research Report, The Aluminium Association. (2007)

[3] Humas UGM.: Teknik Kimia UGM Berhasil Kembangkan Teknologi Proses Produksi Biodiesel secara Kontinu. (2009) http://www.ugm.ac.id/id/berita/1263teknik.kimia.ugm.berhasil.kembangkan.teknologi.pro ses.produksi.biodiesel.secara.kontinu, (online accessed 7 April 2014).

[4] International Business Machines.: IBM ILOG CPLEX V12.1: IBM ILOG CPLEX for Microsoft Excel User's Manual, United States. (2009)

[5] Kaparang, L.: Analysis of Advantage of Small Industry "Allen” Bread, Jurnal Universitas Sam Ratulangi, Manado. (2014)

[6] Lestari, I.R.: Perancangan Jaringan Suplai Minyak Jelantah Untuk Biofuel Di Daerah Istimewa Yogyakarta (DIY), Tesis, Universitas Gadjah Mada, Yogyakarta. (2015)

[7] Mariana, R.R., dan Subandi.: Pemetaan Potensi Kota Malang Sebagai Pemasok Minyak Goreng Bekas Untuk Produksi Biodiesel, Teknologi Dan Kejuruan, 33, 193-200. (2010)

[8] Mugi, P.B., and Harjanto, D.G.: Perancangan Pabrik Etanol Fuel Grade dengan Kapasitas 1000 L/Hari, Executive Summary, Universitas Diponegoro, Semarang. (2011)

[9] Soeharto, I.: Manajemen Proyek Dari Konseptual Sampai Operasional, Penerbit Erlangga, Jakarta. (1995)

[10] Yong, A., Xiangtai, B., Gang, R., Xiaohua, C., and Jian, L.: Analysing the Status, Obstacles and Recommendations For WCOs of Restaurants as Biodiesel Feedstocks in China From Supply Chain' Perspectives, Resources, Conservation and Recycling, 60, 2037. (2012) 